\title{
Asimetrias craneofaciales: análisis radiográfico en los planos frontal y basal en individuos de ambos sexos de 18 a 22 años
}

\author{
Craniofacial asymmetry: radiographic analysis in the frontal and transverse planes in subjects aged 18 to 22 years of \\ both sexes
}

Las asimetrías faciales constituyen una de las áreas críticas en el ámbito de la cirugía craneo-maxilo-facial. La relativa alta incidencia de las mismas unida a la extrema complejidad de algunas de ellas, hace de este campo uno de los retos terapéuticos de nuestra especialidad.

Se ha publicado abundante literatura sobre el manejo terapéutico de las asimetrías, y sin embargo pocos autores se han preocupado de estudiar a fondo los aspectos epidemiológicos de esta patología.

El presente trabajo aporta información relevante sobre la incidencia de asimetrías craneofaciales, a partir de una muestra importante de individuos. Desde el punto de vista metodológico, cabe destacar la dificultad de realizar un análisis bidimensional en tres planos, de una entidad tridimensional con infinitos planos.

Los autores han recurrido al análisis de dos tipos de radiografías convencionales (frontal y basal), y de forma manual -y por tanto más sujeta a interpretación subjetiva-, han seleccionado diversas estructuras y adjudicado las mismas a tres planos en cada una de las proyecciones. Hemos echado de menos la representación de uno de los casos evaluados, con la explicación gráfica del método seguido. En el texto no se entiende demasiado bien que estructuras quedan adscritas a cada uno de los planos en la proyección frontal.

Es interesante constatar el hecho de que -en la serie evaluada, el $76 \%$ de los individuos presentan una asimetría en el plano frontal, y el $54 \%$ en el plano basal. También lo es el hecho de que los varones muestren mayos incidencia de asimetrías que las mujeres.

No conseguimos interpretar adecuadamente la mayor incidencia de asimetrías en el plano medio de la proyección frontal, y tampoco la mayor preponderancia de lateralidad derecha en el plano frontal e izquierda en el lateral. Los datos obtenidos sin embargo, aun siendo interesantes, adolecen de datos sobre la significancia estadística de los mismos.

El advenimiento hace ya más de una década de la radiología tridimensional, hace que este tipo de estudios empiecen a quedar algo obsoletos incluso antes de ver la luz. La generalidad de los estudios realizados en los últimos años sobre asimetrías craneofaciales, están basados en estudios en tres dimensiones.

Yu y cols., ${ }^{1}$ analizan imágenes tridimensionales obtenidas con laser de superficie y concluyen que la alta precisión del método lo hace recomendable en el análisis de la asimetría craneofacial. Es evidente que este tipo de tecnología escapa de las posibilidades de la mayoría de los que nos dedicamos a estos tratamientos, además esta tecnología analiza la asimetía en superficie no siendo capaz de discernir que parte de la misma corresponde al esqueleto y cual a
Facial asymmetry is a critical area in cranio-maxillo-facial surgery. The relatively high incidence of facial asymmetry and the extreme complexity of some asymmetries mean that this field is a therapeutic challenge to our specialty.

Much literature has been published on the therapeutic management of asymmetries, but few authors have taken the time to study the epidemiologic aspects of this pathology thoroughly.

The present study offers relevant information on the incidence of craniofacial asymmetry in a large sample of subjects. From the methodologic point of view, the difficulty of making a bidimensional analysis in three planes of a threedimensional condition that has an infinite number of planes should be emphasized.

The authors resorted to analyzing two types of conventional radiography (frontal and transverse). The authors made a manual selection, which is more prone to subjective interpretation, of diverse structures and assigned them to three planes in each of the projections. We would have appreciated seeing an illustration of one of the cases evaluated with a graphic depiction of the method used. In the text it is not very clear which structures are assigned to each plane in the frontal projection.

It is interesting to note that in the series evaluated $76 \%$ of the subjects had asymmetry in the frontal plane and 54\% in the transverse plane. It also was interesting that the men had a higher incidence of asymmetry than the women.

We cannot properly interpret the higher incidence of asymmetry in the intermediate plane of the frontal projection or the greater preponderance of right side asymmetry in the frontal plane and of left side asymmetry in the lateral plane. The data reported, although interesting, lack information on the statistical significance of the findings.

As a result of the development more than a decade ago of three-dimensional radiology, this type of study is almost obsolete before it is published. The majority of the studies made in recent years on craniofacial asymmetries are based on three-dimensional studies.

Yu et al. ${ }^{1}$ analyze three-dimensional images obtained with surface laser and conclude that the high precision of the method makes the analysis of craniofacial asymmetry advisable. It is evident that this type of technology is not available to most of us who are involved in therapy. In addition, this technology analyzes the surface asymmetry but 
los tejidos blandos. Sin embargo, existen sistemas más baratos y accesibles para la mayoría que permiten un análisis 3D de una entidad-el esqueleto craneofacial- que también es 3D.

Algunos autores han realizados estudios epidemiológicos de asimetrías mediante el análisis tridimensional de cráneos secos. ${ }^{2,3}$ Esta aproximación sin embargo, limita el tamaño de la muestra, e impide cualquier tipo de esfuerzo terapéutico.

Pelo y cols. ${ }^{4}$ emplean el TC 3D para evaluar 10 pacientes con asimetrías faciales, empleando el plano de Frankfurt y el plano LS (que discurre por los canales semicirculares laterales) como planos de referencia. Concluyen que este último plano constituye una referencia estable en pacientes con grandes asimetrías. Es interesante que con la aproximación 3D a este tipo de análisis, el plano de Frankfurt, finalmente deja de ser una línea y pasa a ser un plano real.

Finalmente, la tecnología de análisis radiológico craneofacial tridimensional, permite además la simulación de escenarios terapéuticos, y eventualmente la generación de férulas quirúrgicas que faciliten la realización de los mismos.5,6

Es evidente que el empleo de TC para este tipo de estudios, podría rayar en lo no aceptable por un comité ético. La cantidad de radiación no estaría justificada en un estudio de screening como el planteado por los autores.

Sin embargo, el scanner tridimensional de haz cónico (CBCT), proporciona unos niveles de radiación solo sensiblemente superiores a los de las dos radiografias simples usadas por los autores con cada individuo del estudio. Por otra parte, proporcionan un nivel de información muy superior a la obtenida de la radiología 2D, y mediante el software adecuado, permiten la comparación de infinitos puntos de manera más precisa y rápida.

Felicitamos a los autores por su estudio y los animamos a continuar esta línea de investigación, empleando imágenes 3D que aporten más información al tiempo de faciliten su trabajo y amplíen el volumen de información obtenido del mismo.

Federico Hernández Alfaro Clínica Teknon, Barcelona, España is not capable of discerning what part of the surface corresponds to the skeleton and what part to soft tissues. However, there are cheaper and more accessible systems for the majority that allow 3D analysis of a condition of the craniofacial skeleton, which also is three-dimensional.

Some authors have made epidemiologic studies of asymmetries by three-dimensional analysis of clean skulls.2,3 This approach, however, limits sample size and impedes any type of therapeutic effort.

Pelo et al. ${ }^{4}$ use 3D CT to evaluate 10 patients with facial asymmetries, using the Frankfurt plane and the LS plane (which intersects the lateral semicircular canals) as the reference planes. They conclude that the LS plane is a stable reference in patients with major asymmetries. It is interesting that with the 3D approach to this type of analysis, the Frankfurt plane finally stops being a line and becomes a real plane.

Finally, the technology of three-dimensional craniofacial radiologic analysis also allows the simulation of therapeutic scenarios and, eventually, the generation of surgical splints to facilitate therapeutic interventions. 5,6

It is evident that the use of CAT for this type of studies would be unacceptable to an ethics committee. The amount of radiation exposure would not be justified in a screening study like the one made by the authors.

However, conical beam computed tomography (CBCT) delivers levels of radiation only somewhat greater than that of the two plain radiographs used by the authors for each subject in the study. In contrast, CBCT provides much better information than that obtained by $2 D$ radiology. Using proper software, comparisons of infinite points can be constructed more precisely and rapidly.

We congratulate the authors for their study and we encourage them to continue this line of investigation using $3 \mathrm{D}$ images that provide more information in volume and type and facilitate their work.

\section{Bibliografía}

1. Yu Z, Mu X, Feng S, Han J, Chang T. Flip registration procedure of three-dimensional laser surface scanning images on quantitative evaluation of facial asymmetries. J Craniofac Surg 2009;20:157-60.

2. Rossi M, Ribeiro E, Smith R. Craniofacial asymmetry in development: an anatomical study. Angle Orthod 2003;73:381-5.

3. Gözil R, Keskil S, Calgüner E, Kadioglü D, Sevim A, Onal B, Baykaner K. Neurocraneal morphology as determined by asymetries of the skull base. J Anat 1996;189:673-5.

4. Pelo S, Deli R, Correra P, Boniello R, Gasparini G, Moro A. Evaluation of 2 different reference planes used for the study of asymmetric facial malformations. J Craniofac Surg 2009;20:41-5.

5. Gateno J, Xia JJ, Teichgraeber JF, Christensen AM, Lemoine JJ, Liebschner MA, Gliddon MJ, Briggs ME. Clinical feasibility of computer-aided surgical simmulation (CASS) in the treatment of complex cranio-maxillofacial deformities. J Oral Maxillofac Surg 2007;65:728-34.

6. Hernández-Alfaro F, Mair D, Martí C, Biosca MJ. Planificación virtiual y diseño de férulas CAD/CAM en cirugía ortognática: ¿Una nueva era? Rev Esp Ortod 2006;36:363-70. 